\title{
EXPRESSION OF MATRIX FACTORS IN THE PROCESS OF NEOVASCULARIZATION OF INTERVERTEBRAL DISC
}

\author{
EXPRESSÃO DE FATORES DA MATRIZ DURANTE O PROCESSO DE NEOVASCULARIZAÇÃO \\ DO DISCO INTERVERTEBRAL
}

\author{
EXPRESIÓN DE FACTORES DE LA MATRIZ EN EL PROCESO DE NEOVASCULARIZACIÓN \\ DEL DISCO INTERVERTEBRAL
}

Pedro Henrique Isoldi Pohl ${ }^{1,2}$, Thais Cuperman ${ }^{3}$, Thomas Lozito ${ }^{3}$, Takashi Yurube ${ }^{2}$, Rocky Tuan ${ }^{3}$, James Kang ${ }^{2}$, Nam Vo², Luciano Miller Reis Rodrigues ${ }^{1}$

\begin{abstract}
Objective: To investigate the effects of proteins products of endothelial cells (ECs) on the annulus fibrosus (AF) cell metabolism in an in vitro culture. Methods: Human AF cells were expanded in monolayer cultures and treated with proteins from the medium of cell line HMEC-1 (Human Microvascular Endothelial Cells) $(125 \mu \mathrm{g} / \mathrm{ml})$. After $72 \mathrm{~h}$ of treatment RNA was isolated from AF cells for analysis of gene expression and the culture medium was collected for protein expression analysis. Results: The qRT-PCR analysis demonstrated increased gene expression of matrix metalloproteinases (MMPs) in AF cells treated with protein products of endothelial cells compared with cells from control group of AF cells: MMP-1 243.10 times ( $<<0.05)$, MMP-2 1.37 time ( $<<0.05)$, MMP-3 39.83 times ( $<<0.05)$ and MMP-13 5.70 times $(p<0.05)$. In contrast, tissue inhibitors of metalloproteinases (TIMPs) were suppressed; TIMP-2 $(0.55$ time) $(p<0.05)$ and TIMP-3 (0.60 time) $(p<0.05)$ in the exposed groups. The expression of aggrecan gene $(0.83$ time $)(p<0.05)$, an important extracellular matrix component, was also reduced. MMP-1 and MMP-3 detection was performed, confirming the results of PCR by Western Blot technique. Conclusions: In this study, we observed that the proteins produced by ECs induced the MMPs expression and suppressed the TIMPs as well as the aggrecan in primary cells of the human intervertebral disc, targeting the development of potential treatments for intervertebral disc degeneration and associated discogenic pain.
\end{abstract}

Keywords: Intervertebral disc; Neovascularization pathologic; Matrix metalloproteinases.

\section{RESUMO}

Objetivo: Analisar o efeito de produtos proteicos de células endoteliais (CEs) sobre o metabolismo de células de ânulo fibroso (AF) em ambiente controlado de cultura celular in vitro. Métodos: Células de AF humano foram expandidas em camada única e tratadas com proteínas obtidas a

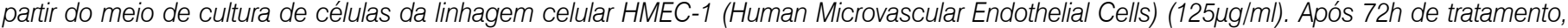
isolou-se RNA das células de AF para análise da expressão gênica e coletou-se meio de cultura para análise de expressão proteica. Resultados: A análise da qRT-PCR demonstrou aumento da expressão gênica das metaloproteinases de matriz (MMPs) nas células de AF tratadas com produtos proteicos das células endoteliais, em comparação com grupo controle de células de AF: MMP-1 243,10 vezes ( $p<0,05)$, MMP-2 1,37 vezes ( $p<$ $0,05), M M P-339,83$ vezes $(p<0,05)$ e MMP13 5,70 vezes $(p<0,05)$. Em contraste, os inibidores teciduais das metaloproteinases $($ TIMPs) apresentaram supressão da expressão gênica de TIMP-2 $(0,55$ vezes) $(p<0,05)$ e TIMP-3 $(0,60$ vezes $)(p<0,05)$ nos grupos expostos. A expressão do gene agrecan (0,83 vezes) ( $p<0,05)$, componente importante da matriz extracelular, também estava diminuída. Foi realizada detecção de MMP-1 e MMP-3, confirmando os resultados de PCR através de técnica de Western Blot. Conclusões: Neste estudo observamos que proteínas produzidas pelas CEs induziram a expressão de MMPs e suprimiram a expressão de TIMPs e agrecan nas células primárias do disco intervertebral humano, objetivando desenvo/vimento de potenciais terapias no tratamento da degeneração do disco intervertebral e dor discogênica associada.

Descritores: Disco intervertebral; Neovascularização patológica; Metaloproteinases da matriz.

RESUMEN

Objetivo: Analizar el efecto de los productos de proteína de las células endoteliales (CEs) en el metabolismo celular del anillo fibroso (AF) en sistema in vitro de cultivo controlado. Métodos: Las células del AF humano se ampliaron en monocapa y se las trató con las proteínas

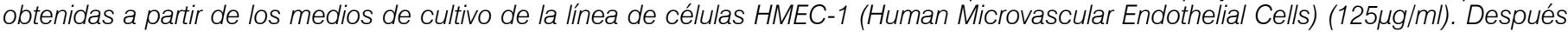
de $72 \mathrm{~h}$ de tratamiento, se aisló el ARN de las células de AF para el análisis de la expresión génica y se recogió el medio de cultivo para el análisis de expresión de la proteína. Resultados: El análisis de qRT-PCR demostró una mayor expresión génica de las metaloproteinasas de matriz (MMP) en las células tratadas con productos de proteína de AF en las células endoteliales, en comparación con el grupo de control de células AF: MMP-1 243,10 veces ( $p<0,05)$, MMP-2 1,37 veces $(p<0,05)$, MMP-3 39,83 veces $(p<0,05)$ y MMP-13 5,70 veces $(p<$ 0,05). En contraste, los inhibidores tisulares de las metaloproteinasas (TIMP), presentaron supresión de la expresión del gen TIMP-2 (0,55 veces) $(p<0,05)$ y TIMP-3 $(0,60$ veces) $(p<0,05)$ en los grupos expuestos. La expresión génica de agrecano $(0,83$ veces) $(p<0,05)$, importante componente de la matriz extracelular, también se redujo. La detección de MMP-1 y de MMP-3 fue realizada y se confirmaron los resultados de la PCR mediante la técnica Western Blot. Conclusiones: En el presente estudio se observó que las proteínas producidas por las CEs indujeron la expresión de MMP y suprimieron la expresión del TIMP y de agrecano en células primarias del disco intervertebral humano, con el objetivo de desarrollar posibles tratamientos para la degeneración del disco intervertebral y el dolor discogénico asociado.

Descriptores: Disco intervertebral; Neovascularización patológica; Metaloproteinasas de la matriz.

1. Faculdade de Medicina do ABC, Orthopedics and Traumatology Discipline, Santo André, SP, Brazil.

2. University of Pittsburgh, Ferguson Laboratory for Orthopaedic and Spine Research, PA, USA.

3. University of Pittsburgh, Center for Cellular and Molecular Engineering, PA, USA.

Study conducted at the Ferguson Laboratory for Orthopaedic and Spine Research University of Pittsburgh (PA), USA.

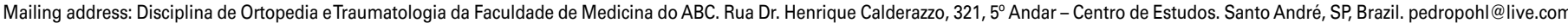




\section{INTRODUCTION}

Spinal diseases related to intervertebral disc degeneration (IDD) represent a global public health problem, due to the physical and psychological limitation it causes, and the substantial associated economic losses. Around $80 \%$ of the population will experience more than one episode of back pain in the course of their lives, and more than $80 \%$ of the population exhibit some sign of disc degeneration on magnetic resonance imaging after 50 years..$^{1-3}$ IDD is associated with pathological conditions of the vertebra, including spinal canal stenosis, foraminal stenosis and spinal disc herniation, often resulting in pain and/or neurological deficit and, ultimately, functional impairment. 4,5

Intervertebral discs (IVDs), which are fibrocartilaginous structures located between the vertebral bodies, are responsible for the absorption, distribution and transmission of loads in the spinal column. They are macroscopically composed of annuli fibrosi (AFs), rich in type 1 collagen, and nucleus pulposus (NP), composed primarily of type 2 collagen and hydrophilic proteoglycans in a complex structure that includes cells, extracellular matrix (ECM) and 70\% water..$^{6,7}$

The development of IDD is related to genetic predisposition, excessive load, smoking, and the natural aging process. ${ }^{8,9}$ Many studies on the cellular mechanisms of IDD have demonstrated the importance of maintaining extracellular matrix homeostasis, striving for a balance between the synthesis and the catabolism of its components. ${ }^{10,11}$ However, natural history, as well as the biological mechanisms that lead to IDD, still have gaps to be filled.

IDD presents water loss through the NP, with a consequent reduction in disc height, and AF fissures, sometimes followed by neovascularization process and neuronal growth, as published previously by Johnson et $\mathrm{a} \mathbf{l}^{12}$ and Stefanakis et al. ${ }^{13} \mathrm{AF}$ invasion by vascular tissue is considered a pathological alteration, as the IVDs are avascular structures.

The cell type most commonly associated with the neovascularization process is that of the endothelium colony-forming cells, or simply endothelial cells (ECs). ${ }^{14,15}$ During the process of invasion, remodeling, and reorganization into newly formed vessels, the ECs will potentially submit the native cells of the intervertebral disc to a completely new environment.

In a study by Moon et $\mathrm{al},{ }^{16}$ the cells of the already degenerated disc are seen to play an important role in the invasion of the endothelial cells, stimulating migration, the production of matrix remodeling factors and growth factors, such as the neuron growth factor.

Based on the article by Moon et al, ${ }^{16}$ we posed the following questions: Could the opposite also be true? Could the endothelial cells be capable of modulating the gene expression of the AF cells? What is the role of endothelial cells in the disc degeneration process?

Although neovascularization has been documented in degenerated discs and in herniated disc content, ${ }^{17,18}$ there are no reports in literature that directly assess the paracrine effect of the endothelial cells on the AF cells in a controlled cell culture environment.

The goal of this study is to ascertain whether soluble endothelial cell protein products can negatively affect the metabolism of the extracellular matrix of the annulus fibrosus in a controlled in vitro cell culture environment.

\section{METHODS}

The design of this study is summarized in diagrammatic form, represented in Figure 1.

\section{Cell Cultures}

Samples of cell line HMEC-1 (Human Micro Endothelial Cells), developed and kindly provided to one of our collaborators by the United States Center for Disease Control and Prevention (CDC), were cultivated in a specific culture medium (EGM-2 MV medium; Lonza, Basel, Switzerland) until confluence of $95 \%$, when the culture medium to be used in the treatment of the annulus fibrosus cells

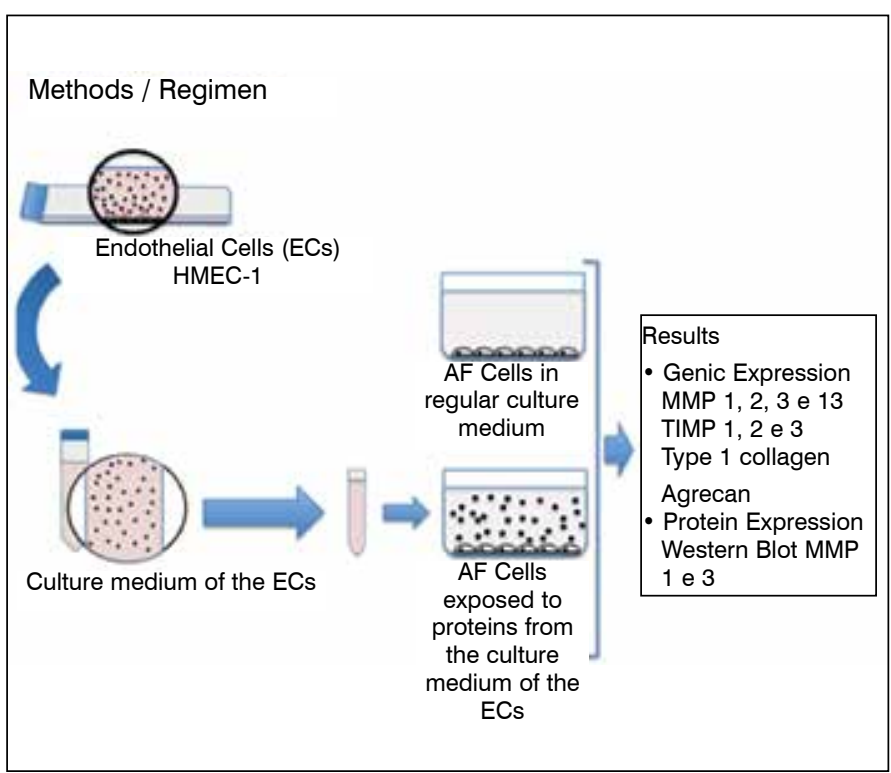

Figure 1. Flowchart of production of the culture medium of the ECs, isolation of the protein products, treatment regimen of the AF cells, and outcomes evaluated.

was collected. Phenotypic characteristics of the endothelial cells were confirmed as described previously. ${ }^{19}$

Cells of human annulus fibrosus samples were obtained from intervertebral discs removed in elective surgical procedures, and sent for cell culture under previous authorization granted by the subjects (Research Ethics Committee of the University of Pittsburgh, PA, USA, protocol number: PRO12100603). The samples were washed, fragmented and digested for 60 minutes at $37^{\circ} \mathrm{C}$ under gentle agitation in an F-12 culture medium containing 5\% fetal bovine serum (FBS), 1\% penicillin/streptomycin (P/S), and $0.2 \%$ pronase (Calbiochem ${ }^{\circledR}$, La Jolla, CA, USA) followed by 18 hours in an $\mathrm{F}-12$ medium containing $5 \% \mathrm{FBS}, 1 \% \mathrm{P} / \mathrm{S}$ and $0.02 \%$ collagenase $\mathrm{P}$ (Roche Diagnostics ${ }^{\circledR}$, Indianapolis, IN, USA). The post-digestion solution was then submitted to filtration, centrifugation at $2000 \mathrm{rpm}$ for $5 \mathrm{~min}$, and re-suspension of the cells in $\mathrm{F}-12$ medium with 10\% FBS and $1 \% \mathrm{P} / \mathrm{S}$, after which they were expanded in conventional culture flasks incubated at $37^{\circ} \mathrm{C}$ in a humidified atmosphere with $5 \%$ carbon dioxide.

All the experiments were conducted with ECs with less than 10 passes, and with AF cells, primary cells, exclusively in the first pass.

\section{Preparation of the Culture Medium Obtained from the Endo- thelial Cells}

ECs, in a concentration of $1 \times 100$ cells $/ \mathrm{cm}^{2}$, were distributed in $150 \mathrm{~cm}^{2}$ culture flasks up to $95 \%$ of confluence, at which time the culture medium was replaced by Dulbecco's Modified Eagle Medium (DMEM), with the addition of $1 \%$ FBS. This is sufficient to maintain the cell functions of the ECs, which continue for 72 hours. After this period the culture medium was collected. This solution was then submitted to successive centrifugation processes, $600 \mathrm{~g}$ and $1500 \mathrm{~g}$ both for 15 minutes at $4^{\circ} \mathrm{C}$, to remove large cell fragments, and $100000 \mathrm{~g}$ for 2 hours at $4^{\circ} \mathrm{C}$ (Beckman XL-70 ultracentrifuge, rotor SW40Ti, Beckman Coulter, Inc., Brea, CA, USA) to remove exosomes and microvesicles potentially released by the ECs.

As the end result of this process, we obtained a supernatant containing proteins secreted by the endothelial cells in the culture medium, clarified of any cell vestiges. The supernatant was concentrated through a centrifugal filter unit (Amicon Ultra-15 $3 \mathrm{kDa}$ NMWL; Millipore Ltd., Carrigtwohill, IRL) and submitted to protein concentration analysis using a Bicinchoninic Acid (BCA $\left.{ }^{\mathrm{TM}}\right)$ Protein Assay Kit (Thermo Fisher Scientific). It was then stored for up to 24 hours at $4^{\circ} \mathrm{C}$, until use in the treatment of $\mathrm{AF}$ cells. 


\section{Treatment of Annulus Fibrosus Cells}

As mentioned above, we used AF cells obtained from tissues resulting from surgical procedures, produced in a monolayer culture with up to $50-70 \%$ confluence, on dishes with an area of $9.5 \mathrm{~cm}^{2}(6$ wells), divided into 2 groups: A. Control (CTL): defined by AF cells in regular culture medium in the absence of treatment; $\mathrm{B}$. Exposed $(E X P)$ : defined by AF cells exposed to proteins from the culture medium of the endothelial cells for 72 hours at a concentration of $125 \mu \mathrm{g} / \mathrm{ml}$

After this period, the culture medium in the treatment dishes was collected and stored at $-80^{\circ} \mathrm{C}$ for protein detection trials using Western Blot (WB). The cells were washed twice with Hank's balanced salt solution (HBSS) and collected for quantitative analysis of the real-time polymerase chain reaction (qRT-PCR).

\section{Analysis of Gene Expression (qRT-PCR)}

Total RNA was extracted using a RNeasy Micro Kit (Qiagen, Dusseldorf, Germany), according to the manufacturer's instructions. The RNA concentrations were verified through spectophotometry (Nanodrop ND-1000, Thermo Fisher Scientific Inc., Wilmington, DE, USA). The real-time polymerase chain reaction (qRT-PCR) was performed using the iScript ${ }^{\mathrm{TM}}$ SYBR $^{\circledR}$ Green kit (Bio-Rad Laboratories, Hercules, CA, USA) in an iCycler IQ4 cycler with specific primers and probes for humans (Applied Biosystems, Foster City, CA, USA) for metalloproneinases (MMPs), including MMP-1, MMP-2, MMP-3, MMP-13, tissue inhibitors of metalloproteinases (TIMPS), TIMP-1, TIMP-2 and TIMP-3, collagen type 1 (Col-1), aggrecan (AGC), and glyceraldehyde-3-phosphate (GAPDH) as housekeeping gene. (Table 1) The relative expression of mRNA was calculated using the $\triangle \mathrm{CT}$ method normalized to the GAPDH gene, comparing the results of the control group of AF cells with the group exposed to the proteins originating from the ECs. ${ }^{20}$

Table 1. Sequence of initiators (primers) used in the gene expression analysis through PCR. In the column on the left the anterograde sequences and on the right the reverse sequences.

\begin{tabular}{c|c}
\hline Primers & Sequence of Bases \\
\hline MMP-1 & GAGCTCAACTTCCGGGTAGA / CCCAAAAGCGTGTGACAGTA \\
\hline MMP-2 & GCGCCGTCGCCCATCATCAA / AGCTCTCCTTGGGGCAGCCA \\
\hline MMP-3 & CAAGGAGGCAGGCAAGACAGC / GCCACGCACAGCAACAGTAGG \\
\hline MMP-13 & TGCTTCCTGATGACGATGTAC / TCCTCGGAGACTGGTAATGG \\
\hline TIMP-1 & TGGCTTCTGGCATCCTGTTGTTG / CGCTGGTATAAGGTGGTCTGGTTG \\
\hline TIMP-2 & GAATCGGTGAGGTCCTGTCCTGA / CCTGCACACAAGCCCGGATAAA \\
\hline TIMP-3 & AGGACGCCTTCTGCAACTC / GTACTGCACATGGGGCATCT \\
\hline Col-1 & GCCTTCCTTGACATTGCTGAAGA / CTCCGTTGGACATAGAGAGGGTT \\
\hline AGC & AAGAATCAAGTGGAGCCGTGTGTC / TGAGACCTTGTCCTGATAGGCACT \\
\hline GAPDH & ACCCACTCCTCCACCTTGAC / TCCACCACCCTGTTGCTGTAG \\
\hline
\end{tabular}

\section{Western Blotting Technique}

Protein samples from the culture medium of the control and exposed AF cells were used in the amount of $10 \mu \mathrm{g}$. The samples were exposed to the SDS-Page reducer and transferred to a low fluorescence background membrane (EMD Millipore Corp., Billerica, MA, USA). The membranes were blocked by $3 \%$ milk in TBS-T (0.25\% Tween-20 in TBS) for a 1-hour period, then incubated with the respective primary antibody overnight at $4^{\circ} \mathrm{C}$ (MMP1, MMP-3, Abcam, Cambridge, MA, USA). The next day, the membranes were washed and incubated for $1 \mathrm{~h}$ with the appropriate secondary antibody, diluted at a ratio of 1:25000. Using a Typhoon 9410 imager (GE Healthcare Biosciences, Piscataway, NJ, USA), the bands were visualized using green laser at 532nm in a 526-nm SP filter.

\section{Statistical Analysis}

The results represent the means of the values obtained through assays of samples from four different subjects for each variable obtained in duplicate \pm standard error. The Mann-Witney nonparametric $U$ test was used for the statistical analysis. The results were considered statistically significant through the calculation of a confidence interval of $95 \%$, with values of $\mathrm{p}<0.05$. The computer program SPSS $^{\circledR}$ version $21\left(\mathrm{IBM}^{\circledR}\right)$ was used for the statistical analysis.

\section{RESULTS}

Eight different samples of AF cells were assessed, resulting from surgical spinal procedures of subjects with an average age $43.25 \pm$ standard deviation (SD) of 13.22, degree of degeneration according to Pfirmann et $a^{21}$ of $2.360 .74 \pm S D$, and the following additional characteristics, as shown in Table 2.

Images of the cell cultures in a light field were obtained after 72 hours of treatment. A slight difference was noted between the groups, with a slight decrease in cell turgescence in the group exposed to the culture medium of the endothelial cells, yet without any apparent increase of cell apoptosis related to the treatment applied. (Figure 2)

The RT-PCR analysis demonstrated an increase in gene expression of the metalloproteinases in the AF cells treated with protein products of the endothelial cells. MMP-1 exhibited a 243.10-fold increase $(p<0.05)$ in the gene expression of the exposed group, compared to the control group, MMP-2 demonstrated a 1.37-fold increase $(p<0.05)$, MMP-3 a 39.83-fold increase $(p<0.05)$, and MMP-13 a 5.70 -fold increase $(p<0.05)$ in gene expression (Figures $3 \mathrm{~A}$ and $\mathrm{B})$.

In contrast, the gene expression of tissue inhibitors of metalloproteinases (TIMPS) exhibited suppression of the TIMP-2 (0.55fold) $(p<0.05)$ and TIMP-3 $(0.60$-fold $)(p<0.05)$ genes in the groups exposed to the proteins of the culture mediums of the ECs, compared to the control group. The expression of aggrecan (0.83-fold) $(p<0.05)$, an important component of the extracellular matrix, was also decreased. The TIMP-1 (1.05-fold) $(p=0.48)$ and collagen type I $(0.79$-fold $)(p=0.219)$ genes did not exhibit any statistically significant differences between groups. (Figure 3C)

\section{Detection of MMP-1 and MMP-3 by the Western Blot technique}

The MMP-1 and MMP-3 proteins were selected for detection using Western Blot. The membranes loaded with proteins from the culture medium of the AF cells of the CTL and EXP groups are represented in Figure 4. This analysis was carried out on four different specimens, presenting consistency of results.

Table 2. Characteristics of the donors of intervertebral disc tissue for cell culture.

\begin{tabular}{c|c}
\hline Characteristics & Values \\
\hline Gender (Male:Female) & $4: 4$ \\
\hline Age (Mean \pm SD) & $43.25 \pm 13.22$ \\
\hline Segment (Cervical:Lumbar) & $7: 1$ \\
\hline Degree of Degeneration (Mean \pm SD) & $2.36 \pm 0.74$ \\
\hline Smoker (Yes:No) & $3: 5$ \\
\hline
\end{tabular}

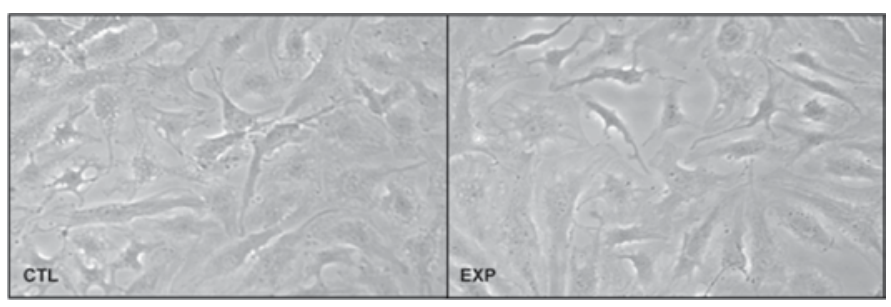

Figure 2. Comparison of the AF cell cultures after treatment. On the left control group (CTL), and on the right group exposed (EXP) to the EC proteins. 


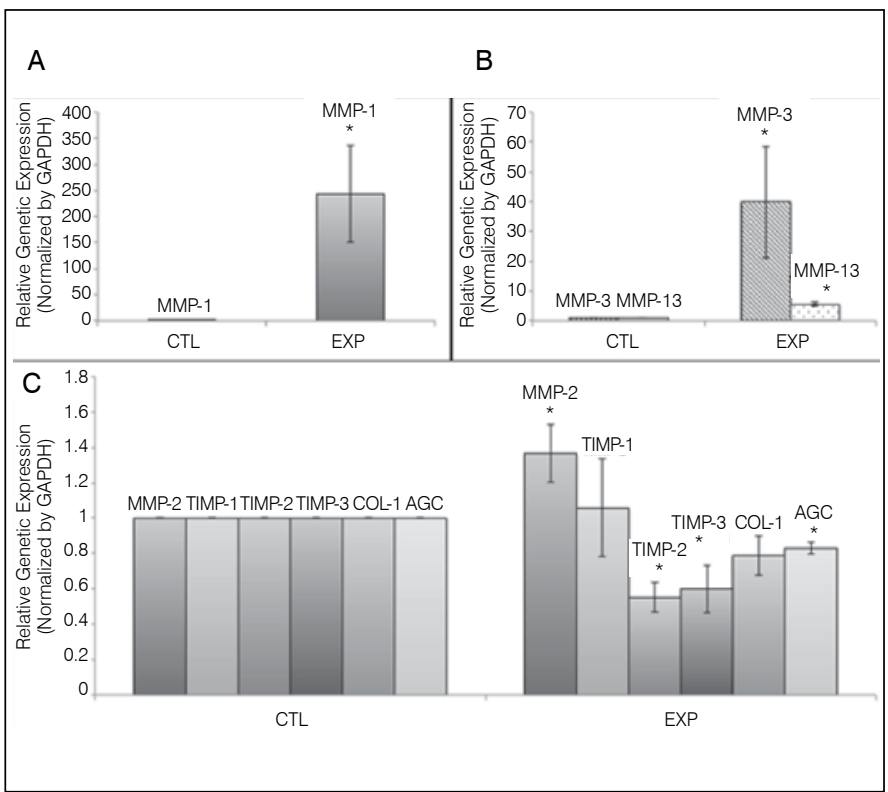

Figures 3. $A, B$ and $C$. Analysis of the relative gene expression normalized by the GAPDH gene of AF cells of the control (CLT) and exposed (EXP) groups. Statistically significant differences are marked with "*" and represent $p<0.05$.

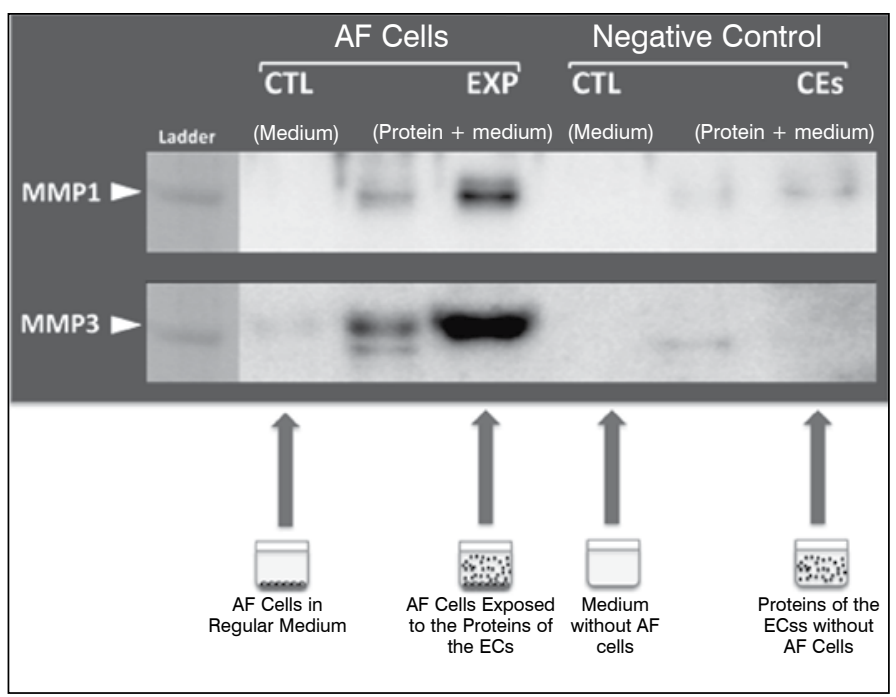

Figure 4. Detection membranes of proteins MMP-1 and MMP-3 by the Western Blot technique. On the left comparison of the culture mediums of AF cells of the control group (CLT) and exposed group (EXP). On the right, detection in negative cell control, i.e., virgin culture medium and culture medium of the endothelial cells before being used in the treatment of the AF cells.

\section{DISCUSSION}

IVD homeostasis is in a delicate balance between the production and degradation of MEC components, essential to maintain the hydric composition of the IVD ${ }^{11,22}$ which is naturally avascular except for the outer region of AF. Nutrition occurs through diffusion and basically takes place through two routes: through the end plate responsible for the interface with the adjacent vertebral bodies and through the vascular system that surrounds the outside of the $\mathrm{AF}^{23,24}$

Based on previous findings in the literature that indicate a relationship between intervertebral disc degeneration and the growth of neovessels in the $A F,{ }^{14,15,18}$ this study evaluated the possible paracrine effects of the endothelial cells on the annulus fibrosus cells, with the aim of imitating the microenvironment of the process of neovascularization and degeneration of the intervertebral disc through controlled, in vitro experiments. This survey was motivated by the absence of studies demonstrating the role played by the endothelial cells in this sequence of events.

Stefanakis et $a /^{13}$ uphold that annulus fibrosus fissures are a pathway for vascular and neuronal growth inside the AF, while Johnson et $a /^{12}$ demonstrated in one of their articles that proteoglycans, one of the main components of the extracellular matrix of normal discs, are potentially responsible for inhibiting vascular growth inside the disc. Ratsep et al, ${ }^{18}$ on the other hand, stressed the importance of neovascularization in the reabsorption of disc tissue of extruded hernias.

Our study is unique, as it assesses effects produced by the endothelial cells on the native AF cells, imitating the initial period of the neovascularization process. After treatment of the disc cells with EC protein products, we assessed the matrix metalloproteinase expression variations, tissue inhibitors of metalloproteinases, collagen type I and aggrecan.

Metalloproteinases are zinc-dependent endopeptidases. These enzymes are able to degrade most extracellular matrix proteins and therefore play an important role in the remodeling of the matrix. Twenty-eight MMPs have been described so far, of which 24 are detected in vertebrates and 23 in humans. ${ }^{25}$ Some are considered key enzymes in the intervertebral disc degeneration process. These include MMP-1 (interstitial collagenase), MMP-2 (gelatinase A), MMP-3 (Stromelysin-1) and MMP-13 (collagenase 3). ${ }^{22}$

Moon et $a /^{16}$ recently noted that IVD cells, in different degrees of degeneration, stimulate endothelial cells to produce key degradation markers of the extracellular matrix (MMP-2, MMP-13) and neuron growth factor, a mechanism potentially associated with discogenic pain.

In our results we were able to observe that the AF cells, when in contact with the proteins produced by the ECs, exhibited increased gene expression of key MMPs for the catabolism of MEC (MMP-1, MMP-3 and MMP-13). The two MMPs expressed the most, MMP-1 and MMP-3, also were analyzed through western blot for direct detection, and the results were confirmed by PCR.

In contrast, it was found that the gene expressions of the TIMPs, tissue inhibitors of the matrix metalloproteinases, whose main function is to neutralize the action of the MMPs, were suppressed, with TIMP-2 and TIMP-3 of $45 \%$ and $40 \%$, respectively. We also noted suppression of the gene expression at $17 \%$, one of the main proteins that constitute the MEC of the annulus fibrosus. ${ }^{24}$

The imbalance between the production of MEC formers (collagen and aggrecan) and factors responsible for its degeneration (MMPs and TIMPs) allows us to predict, in vitro, that the ECs trigger a potential catabolic profile of the expression of proteins in the native AF cells during the early vascular invasion stages. However, which are the proteins known to be produced by the ECs that could potentially induce this behavior in the intervertebral disc cells?

Many factors are known to be produced by the ECs. Among these, MMP-2, MMP-13, MMP-14, Interleukin 1-beta (IL-1B) and plasminogen were detected in the culture medium of type HMEC-1 ECs. ${ }^{16,19}$ It is possible that these MMPs, IL-1B, and plasminogen, are directly related to the behavior exhibited by the AF cells. The remodeling of $\mathrm{MEC}$ in a dense tissue such as the $\mathrm{AF}$ is a prerequisite for vascular invasion as an attempt at tissue regeneration.

However, it was noted that AF healing is often inefficient, even after an intense neovascularization process. ${ }^{26}$ We raised the possibility that the growth of neovessels within the intervertebral disc degeneration process may have an effect contrary to the healing attempt, i.e., a catabolic effect, thus increasing the breakage of the MEC and suppressing the production of factors responsible for its synthesis and consequent homeostasis.

\section{CONCLUSION}

Although the study submitted has the limitations inherent to in vitro studies, we were able to observe, in a controlled environment, the potential deleterious effects of the endothelial cells on the primary cells of the human intervertebral disc, and thereby design a microbiological scenario possibly established during the intervertebral disc neovascularization and degeneration process. 
Additional in vitro studies, besides confirming the results in vivo, are necessary to obtain additional information about the factors produced and secreted by the endothelial cells during the vascular and neuronal invasion process, with the aim of developing potential therapies for the treatment of intervertebral disc degeneration and associated discogenic pain.

\section{ACKNOWLEGEMENTS}

The authors are grateful to CAPES (Coordenação de Aperfeiçoamento de Pessoal de Nível Superior), the Science without Fronteirs program, the Graduate Studies Department of the Faculdade de Medicina do ABC, ISLLS Macnab/Larocca Research Fellowship Award 2012 granted to Pedro Pohl, The Albert B. Ferguson Fund of The Pittsburgh Foundation, Drs. Bing Wang and Ying Tang (Molecular Therapy Laboratory), and for the continual technical support provided by the Ferguson Laboratory team.

All authors declare no potential conflict of interest concerning this article.

\section{REFERENCES}

1. Schwarzer AC, Aprill CN, Derby R, Fortin J, Kine G, Bogduk N. The prevalence and clinical features of internal disc disruption in patients with chronic low back pain. Spine (Phila Pa 1976). 1995;20(17):1878-83.

2. Peng $B, F u X$, Pang $X$, Li D, LiuW, Gao $C$, et al. Prospective clinical study on natural history of discogenic low back pain at 4 years of follow-up. Pain physician. 2012;15(6):525-32.

3. Matsumoto M, Okada E, Toyama Y, Fujiwara H, Momoshima S, Takahata T. Tandem age-related lumbar and cervical intervertebral disc changes in asymptomatic subjects. Eur Spine J. 2013;22(4):708-13.

4. Bendix T, Kjaer P, Korsholm L. Burned-out discs stop hurting: fact or fiction? Spine (Phila Pa 1976). 2008;33(25):E962-7.

5. Rodrigues LM, Theodoro TR, Matos LL, Mader AM, Milani C, Pinhal MA. Heparanase isoform expression and extracellular matrix remodeling in intervertebral disc degenerative disease. Clinics (Sao Paulo). 2011;66(5):903-9.

6. Hoyland JA, Le Maitre C, Freemont AJ. Investigation of the role of IL-1 and TNF in matrix degradation in the intervertebral disc. Rheumatology (Oxford). 2008;47(6):809-14.

7. Roberts S. Disc morphology in health and disease. Biochem Soc Trans. 2002;30(Pt 6):864-9.

8. Battie MC, Videman T, Gibbons LE, Fisher LD, Manninen H, Gill K. 1995 Volvo Award in clinical sciences. Determinants of lumbar disc degeneration. A study relating lifetime exposures and magnetic resonance imaging findings in identical twins. Spine (Phila Pa 1976). 1995;20(24):2601-12.

9. Vo N, Seo HY, Robinson A, Sowa G, Bentley D, Taylor L, et al. Accelerated aging of intervertebral discs in a mouse model of progeria. J Orthop Res. 2010;28(12):1600-7.

10. Studer RK, Aboka AM, Gilbertson LG, Georgescu H, Sowa G, Vo N, et al. P38 MAPK inhibition in nucleus pulposus cells: a potential target for treating intervertebral disc degeneration. Spine (Phila Pa 1976). 2007:32(25):2827-33.

11. Wang D, Nasto LA, Roughley P, Leme AS, Houghton AM, Usas A, et al. Spine degeneration in a murine model of chronic human tobacco smokers. Osteoarthritis Cartilage. 2012;20(8):896-905

12. Johnson WE, Caterson $B$, Eisenstein SM, Roberts S. Human intervertebral disc aggrecan inhibits endothelial cell adhesion and cell migration in vitro. Spine (Phila Pa 1976). 2005;30(10):1139-47.

13. Stefanakis M, Al-Abbasi M, Harding I, Pollintine P, Dolan P, Tarlton J, et al. Annulus fissures are mechanically and chemically conducive to the ingrowth of nerves and blood vessels. Spine (Phila Pa 1976). 2012;37(22):1883-91.

14. Nerlich AG, Schaaf R, Walchli B, Boos N. Temporo-spatial distribution of blood vessels in human lumbar intervertebral discs. Eur Spine J. 2007;16(4):547-55.

15. Adams MA, Stefanakis M, Dolan P. Healing of a painful intervertebral disc should not be confused with reversing disc degeneration: implications for physical therapies for discogenic back pain. Clin Biomech (Bristol, Avon). 2010;25(10):961-71.

16. Moon $\mathrm{HJ}$ Y Yurube T, Lozito TP Pohl P Hartman RA Sowa GA et al. Effects of secreted factors in culture medium of annulus fibrosus cells on microvascular endothelial cells: elucidating the possible pathomechanisms of matrix degradation and nerve in-growth in disc degeneration. Osteoarthritis Cartilage. 2014;22(2):344-54.

17. Lama $P$, Le Maitre $C L$, Dolan P, Tarlton JF, Harding IJ, Adams MA. Do intervertebral discs degenerate before they herniate, or after? Bone Joint J. 2013;95-B(8):1127-33.

18. Ratsep T, Minajeva A, Asser T. Relationship between neovascularization and degenerative changes in herniated lumbar intervertebral discs. Eur Spine J. 2013;22(11):2474-80.

19. Lozito TP, Tuan RS. Endothelial cell microparticles act as centers of matrix metalloproteinsase-2 (MMP-2) activation and vascular matrix remodeling. J Cell Physiol. 2012;227(2):534-49.

20. Livak KJ, Schmittgen TD. Analysis of relative gene expression data using real-time quantitative PCR and the 2(-Delta Delta C(T)) Method. Methods. 2001:25(4):402-8.

21. Pfirrmann CW, Metzdorf A, Zanetti M, Hodler J, Boos N. Magnetic resonance classification of lumbar intervertebral disc degeneration. Spine (Phila Pa 1976). 2001:26(17):1873-8.

22. Vo NV, Hartman RA, Yurube T, Jacobs LJ, Sowa GA, Kang JD. Expression and regulation of metalloproteinases and their inhibitors in intervertebral disc aging and degeneration. Spine J. 2013:13(3):331-41.

23. Grunhagen T, Shirazi-Adl A, Fairbank JC, Urban JP. Intervertebral disk nutrition: a review of factors influencing concentrations of nutrients and metabolites. Orthop Clin North Am. 2011;42(4):465-77.

24. WuY, Cisewski S, Sachs BL, Yao H. Effect of cartilage endplate on cell based disc regeneration: a finite element analysis. Mol Cell Biomech. 2013;10(2):159-82.

25. Visse R, Nagase H. Matrix metalloproteinases and tissue inhibitors of metalloproteinases: structure, function, and biochemistry. Circ Res. 2003:92(8):827-39.

26. Hampton D, Laros G, McCarron R, Franks D. Healing potential of the anulus fibrosus. Spine (Phila Pa 1976). 1989;14(4):398-401. 